\title{
PELITUTKIMUSTA KOREASSA - keskittymistä teknologiaan ja pelihaittoihin?
}

Kun puhutaan peliteollisuuden, peliharrastuksen tai kilpapelaamisen suurista maista, Etelä-Korea nousee esiin yhtenä suurimmista. Vuonna 2017 Korean kotimaiset pelimarkkinat olivat vajaan 10 miljardin euron arvoiset ja niiden on ennustettu kasvavan tasaisesti. Globaalisti tarkasteltuna korealaiset pelimarkkinat olivat neljänneksi suurimmat Kiinan, Japanin ja USA:n jälkeen. Pelkkien PC-pelien kohdalla Korea oli kolmantena. (Kocca 2018.) Lähes 30 miljoonaa korealaista, eli reilu puolet maan asukkaista, pelaa digitaalisia pelejä aktiivisesti (South Korea Games Market 2018).

Oma lukunsa korealaisessa pelaamisessa on maan menestys elektronisen urheilun parissa. Maata on tutkimuksessa kutsuttu jopa e-urheilun mekaksi (Taylor 2012), sillä e-urheilu on ollut siellä jo pitkään huomattavasti suositumpaa, ammattimaisempaa ja järjestäytyneempää kuin länsimaissa. Siinä missä länsimaiset pelijoukkueet, ammattilaispelaajat ja kilpailuiden järjestäjät vasta yrittivät ratkaista erilaisia kannattavuuteen ja jatkuvuuteen liittyviä ongelmia koko 2000-luvun ensimmäisen vuosikymmenen, Koreassa oli jo useampi ammattilaisliiga. Ja vaikka muu maailma onkin saamassa Koreaa kiinni pelitaidoissa, monissa peleissä korealaisia pidetään edelleen parhaimpina pelaajina ja lähes automaattisina voittajasuosikkeina.

Minulla oli keväällä 2019 mahdollisuus matkustaa Etelä-Koreaan reiluksi kahdeksi kuukaudeksi tutustumaan paikalliseen kilpapelikulttuuriin, alan toimijoihin ja pelitutkijoihin. Paikalliseen tutkimukseen ja tutkijoihin tutustuessa syntyi korealaisesta pelialasta ja -tutkimuksesta varsin erilainen kuva kuin Suomessa. Tilanne oli kummallinen: maan menestyksekäs historia pelien kehityksessä ja kilpapelaamisessa sekä nuorison ahkera pelaaminen eivät sovi yhteen jokseenkin yksipuolisen ja haittoihin keskittyneen tutkimuskentän kanssa.

Tämän katsauksen tarkoituksena on avata korealaisen pelitutkimuksen kenttää aihetta käsittelevien systemaattisten kirjallisuuskatsausten avulla sekä pohtia mahdollisia historiallisia, kulttuurisia ja yhteiskunnallisia syitä tutkimusalan tilaan paikallisten tutkijoiden kanssa käymieni keskusteluiden kautta. Kirjallisuuskatsaukset on julkaistu korealaisissa julkaisuissa korean kielellä. Ne on tätä katsausta varten käännetty englanniksi googlen käännöspalvelun avulla (translate.google.fi). Vaikka online-käännössivustot alkavat jo tuottaa jokseenkin ymmärrettävää tekstiä, keskityn tässä lähinnä lähteissä olleiden taulukoiden sisältöön, sillä niiden osalta käännöksestä johtuvat virheet ovat pienempiä ja epätodennäköisempiä. Niiltä osin kuin olen käyttänyt muita korealaisia lähteitä, olen varmistanut kieltä äidinkielenään puhuvilta, että olen ymmärtänyt tekstin oikein.

Pelaamisen suosiosta ja korealaisten peliyritysten ja pelaajien menestyksestä huolimatta korealainen pelitutkimus on maailmalla varsin tuntematonta. Länsimaista ja suomalaista pelitutkimusta muistuttavista näkökulmista tehtyä tutkimusta on lähes 
mahdoton löytää, ja muutamaa tutkijaa lukuun ottamatta vain harva julkaisee lainkaan englanniksi. Vastaavaa tutkimusta ei ole kovin paljoa julkaistu koreaksikaan. Lukiessa paikallisia meta-analyysejä ja katsauksia pelitutkimuksesta on löydettävissä kaksi vahvaa keskittymää: pelien vaikutuksiin (lähinnä riippuvuuteen) keskittynyt psykologinen ja psykiatrinen tutkimus sekä pelien tuotantoon keskittynyt informaatioteknologinen tutkimus (Jeon 2010a). Myös muunlaista pelitutkimusta on Koreassa tehty, mutta verrattuna kahteen aikaisempaan teemaan se on harvinaisempaa ja jälleen keskittynyt tiettyihin omiin teemoihinsa, lähinnä narratologiaan ja hieman uudempana ludologiaan (Jeon 2010b), jossa pelit nähdään omana alanaan eikä niinkään vain uutena kenttänä, johon soveltaa muiden alojen teorioita.

Huomattavaa on, että käyttämäni katsaukset on julkaistu jo lähes vuosikymmen sitten. Valitettavasti en ole onnistunut löytämään näitä uudempia lähteitä. Sen perusteella, mitä paikalliset tutkijat ovat kertoneet, on tutkimuskenttä kuitenkin vasta lähivuosina alkanut muuttua. Aikaisemmat trendit jatkuivat siis varsin pitkälle 2010-luvulle.

\section{Korealaista pelitutkimusta}

Riippuvuutta ja muita pelien mahdollisia haittoja koskeva tutkimus on Koreassa ollut kenties eniten esillä yhteiskunnallisessa keskustelussa. Se on kahden viime vuosikymmenen ajan ollut valtion ja muiden julkisten rahoituslaitosten rahoittaman peliaiheisen tutkimuksen keskiössä. Paikallisten tutkijoiden puheita ja selityksiä kuunnellessa tuntuu kuin yhteiskunta ja rahoittajat olisivat reagoineet voimakkaasti pelien suosion kasvun myötä syntyneeseen moraaliseen paniikkiin niiden vaikutuksista. Nuorison ja lasten on koettu olevan vaarassa, ja tutkimuksen, joka joko todistaa tämän vaaran todelliseksi tai avaa sen mekanismeja, on nähty olevan otollinen ja käytännöllinen tapa osoittaa, että vaara otetaan tosissaan. Varsinkin kun liiallinen pelaaminen on nähty uutena ilmiönä, jonka kaltaista ei ole ennen kohdattu, ja joka siten on ollut hyvin vaikea lähestyä.

Haittojenkin osalta korealainen pelitutkimus on vahvasti keskittynyt yhteen teemaan: pelaamiseen addiktiona, pakkomielteisenä toimintana, jonka lopettaminen on vaikeaa, ja joka vaikuttaa negatiivisesti pelaajan elämään. Jeon Gyong Ran (2010a) meta-analyysissä korealaisen pelitutkimuksen trendeistä analysoiduista reilusta 600 artikkelista 23,4 \% (141) keskittyy pelien vaikutuksiin. Vaikutuksiin keskittyvistä tutkimuksista yli 55 \% tutki pelien aiheuttamaa riippuvuutta (Jeon 2010a). Trendinä näin suuri keskittyminen juuri riippuvuuteen on mielenkiintoinen, sillä vaikka länsimaissa peliriippuvuus onkin saanut osansa mielenkiinnosta, muut mahdolliset pelien haitat, kuten niiden aiheuttama väkivaltaisuus, ovat olleet myös keskiössä.

Vaikka paikalliset pelitutkijat näkivät melkeinpä minkä vain peleihin keskittyvän tutkimuksen olevan edistystä aikaisemmasta, jolloin rahoitusta ei ollut juuri lainkaan, he kokivat nopeasti kasvaneen haittoihin keskittyvän rahoituksen olevan myös varsin ongelmallista. Luonnollisesti tutkimusrahoituksesta on pulaa alasta riippumatta, ja kilpailu sen saamisesta on kovaa. Kun peleihin keskittyvän tutkimuksen rahoitus on kasvanut nopeasti, sitä ovat alkaneet hakea myös tutkijat ja tutkimusryhmät, joiden kokemus peleistä on hyvin puutteellista. Kun he eivät tunne tutkimuskohdettaan juuri lainkaan ja rahoitus on ohjattu hyvin tarkasti haittojen tutkimukseen, on syntynyt kasa tuloksia, joissa pelit on huomattu varsin haitallisiksi, mutta selitykset mekanismeista, miksi ne ovat haitallisia, kuulostavat kenties kummallisilta. Toisaalta uusimpien pelien haittoja koskevan tutkimuksen joukossa on myös sellaisia, jotka toteavat peliaddiktion olevan vain oire muista ongelmista, lähinnä erittäin stressaavasta koulu- ja opiskelijaelämästä, turvaverkkojen ja tuen 
puutteesta ja huonosta suhteesta vanhempiin (ks. esim. Jeong, Ferguson \& Lee 2019). Eui Jun Jeong Konkuk-yliopistosta toteaakin, etteivät pelit itsessään ole se ongelma, eikä niiden kieltäminen auta. Pelit kieltämällä nuorten riippuvuus vain siirtyy johonkin toiseen kohteeseen: sosiaaliseen mediaan, internetiin, elokuviin tai vaikka perinteisempään alkoholiin (Kwak 2019).

Jeonin meta-analyysin mukaan toinen erittäin vahva teema korealaisessa peleihin keskittyvässä tutkimuksessa on ollut pelinkehityksessä. Meta-analyysin artikkeleista 33,2 \% (202 kpl) tutki pelien tuotantoa tavalla tai toisella. Erityisesti pelien teknologinen puoli, niihin liittyvät ohjelmistot sekä pelinkehityksen suunnittelu ja kehitysprosessit ovat olleet tutkijoiden kiinnostuksen kohteena. (Jeong 2010a.) Nämä aihepiirit tukevat peliteollisuuden menestystä ja paikallisten tutkijoiden mukaan osa tutkimuksen rahoituksesta tuleekin usein peliteollisuudelta. Heidän mukaansa aihepiiri on vielä suositumpaa kuin mitä meta-analyysien perusteella voi todeta, sillä monesti aihepiiriin keskittyvää tutkimusta ei julkaista missään, vaan se jää teollisuuden rahoittajien omaan käyttöön, vaikka se olisikin toteutettu korealaisten yliopistojen toimesta.

Riippumatta tutkimuksen tarkemmasta aihepiiristä, ne ovat yleensä keskittyneet laajemmin online-pelien ja digitaalisten pelien tutkimukseen. Jeonin mukaan vain muutamassa tutkimuksessa on tarkemmin määritelty, onko kyseessä ollut konsolipeli, PC-peli vai mobiilipeli. Sen sijaan 92 \% tutkimuksista on ennemmin käytetty yleisempää määritelmää joko digitaalisesta- tai online-pelistä. (Jeon 2010b.) Tämä jako osaltaan reflektoi myös korealaisen yhteiskunnan narratiivia peleistä sekä potentiaalisesti haitallisina että merkittävänä teollisuuden alana. Useimmiten juuri online-pelit on nähty erityisen addiktoivina ja nuorisolle haitallisina. Haittoihin keskittyvässä tutkimuksessa ei ole koettu tarpeelliseksi erotella sen enempää, millä alustalla pelejä on pelattu, vaan pelien pelaaminen internetin välityksellä muiden kanssa on ollut merkityksellisempää. Koreassa pelaamisen suosio lähti nousuun 2000-luvun alussa PC-bangien, eli "PC-huoneiden" tai nettikahviloiden myötä, sillä ne mahdollistivat nuorille nopeammat internet-yhteydet ja halvemmat mahdollisuudet pelata ilman vanhempien valvontaa, kuin mitä kotona omalla koneella oli mahdollista (Jin 2010). Samaten korealainen peliteollisuus on menestynyt juuri online- ja digitaalisten pelien saralla, osaksi myös PC-bangien ansiosta, sillä niiden myötä kasvaneet laajat kotimaiset markkinat ovat olleet otollinen kasvualusta, josta ponnistaa kansainvälisille markkinoille.

Vaikka korealainen pelitutkimus onkin vahvasti keskittynyt pelaamisen haittoihin ja peliteollisuuden tukemiseen, myös muuta pelitutkimusta tehdään jonkin verran. Jeonin meta-analyysin mukaan reilu $6 \%$ pelitutkimuksesta kuului humanistiseen tutkimusperinteeseen. Lisäksi reilu $12 \%$ voidaan laskea taiteiden tutkimukseksi, mutta näistä monet ovat ennemminkin pelien tuotannon tutkimusta kuin varsinaisesti pelejä taiteena tutkivia artikkeleita. Pelikulttuurit, aihe joka on Suomessa ja maailmalla saanut reilun osan pelitutkijoiden huomiosta, on Koreassa jäänyt suurimmaksi osaksi paitsioon, sillä vain 2,3 \% artikkeleista keskittyi siihen. (Jeon 2010a.) Suurin osa humanistisesta tutkimuksesta analysoi pelejä niiden tarinankerronnan näkökulmasta käyttäen yleensä narratiivia lähtökohtanaan - muutama tutkimus oli myös lähestynyt pelejä ludologisesta näkökulmasta. (Jeon 2010a; Jeon 2010b; Jang 2013.) Varsinaista syytä tähän painotukseen ei kirjallisuuskatsauksista löytynyt, mutta haastattelemani tutkijat arvioivat sen johtuvan perinteiden kunnioittamisesta ja tutkijoiden omista lähtökohdista. On helpompaa selittää oman tutkimuksensa tarpeellisuutta, kun voi kertoa nojaavansa vankkaan tutkimusperinteeseen (kuten tarinankerronnan ja narratiivin tutkimukseen), vaikka aihepiiri olisikin jokseenkin erilainen. Huomionarvoista on myös se, että tässä lainatut korealaiset metatutkimukset ovat kohta kymmenen vuotta vanhoja, eikä uudempia tunnu olevan 
saatavilla. On hyvin mahdollista, että tutkimussuuntaukset ovat voineet muuttua ajan kuluessa paljonkin. Tekemieni haastattelujen perusteella vaikuttaa kuitenkin siltä, että ainakaan koko tutkimusalaa mullistavia muutoksia ei ole tapahtunut, vaan tutkimus on suurimmaksi osaksi seurannut entisiä trendejä.

\section{Miten tähän on päästy?}

Bora Na, Sungkyunkwanin yliopistossa pelihistoriaa tutkiva tohtori, selittää nykyistä humanistisen pelitutkimuksen hankalaa asemaa sekä korealaisen yhteiskunnan ristiriitaista suhtautumista videopeleihin historiallisen kehityksen ja yhteiskunnallisten arvojen kautta. Korealaisen yhteiskunnan perinteisiin ja kungfutselaisiin arvoihin videopelien kaltaiset huvitukset eivät sovi. Vaikka nykyaikainen korealainen yhteiskunta on monilta osin vapaampaa ja länsimaistunutta, ovat koulutus, vanhempien ja ylempien kunnioitus ja läpi elämän jatkuva itsensä kokonaisvaltainen kehittäminen edelleen monelle tärkeä malli siitä, miten hyvän ihmisen kuuluisi elää. Tähän malliin istuvat jotenkin sekä go:n tai shakin kaltaiset perinteiset vahvasti strategiset pelit (joiden pelaamisella voidaan ajatella olevan myös käytännön hyötyä) että urheilu, joka kehittää ja ylläpitää fyysistä toimintakykyä. Digitaaliset pelit sen sijaan ovat tästä näkökulmasta turhia, sillä ne on perinteisesti mielletty vain viihteeksi. Korean kielessä videopelejä ja go:n ja shakin kaltaisia strategisia ja perinteikkäitä lautapelejä myös kutsutaan eri sanoilla, ja ne mielletään muutenkin hyvin erilaisiksi asioiksi kuin videopelit. Oman lisänsä kokonaisuuteen tuo se, että ennen Korean oman peliteollisuuden nousua 2000-luvulla monet videopeleistä tulivat Japanista, eikä mitään japanilaista katsottu kovin hyvällä maiden vaikean yhteisen historian vuoksi. (Na 2019.)

Kun Korean talous romahti vuoden 1997 lopussa Aasian talouskriisin (IMF Crisis) myötä, monet nuoret ja korkealle koulutetut ihmiset menettivät työnsä. Nan mukaan työttömyyttä voidaan hyvin pitää alkusysäyksenä korealaiselle peliteollisuudelle. Monet työttömät olivat korkeasti koulutettuja ja työskentelivät aikaisemmin tietotekniikkayrityksissä. Heistä useat päätyivät perustamaan joko omia pelinkehitykseen keskittyviä yrityksiä tai helppona ja kustannuksiltaan halpana vaihtoehtona pidettyjä PC-bangejä. Monet muut taas viettivät työttömyytensä myötä kasvanutta vapaa-aikaansa pelaten pelejä samaisissa PC-bangeissä. (Na 2019.) Saman huomion on tehnyt myös korealaisen peliteollisuuden kasvua tutkinut Dal Yong Jin, jonka mukaan PC-bangit ovat vaikuttaneet huomattavasti niin korealaiseen pelikulttuuriin kuin paikallisen peliteollisuuden menestykseen (Jin 2010, 24-26).

Yhteiskunnan ja hallinnon näkemykset digitaalisista peleistä alkoivat muuttua kuitenkin vasta, kun korealaiset MMORPG-pelit (massiiviset monen pelaajan onlineroolipelit) Lineage I ja II etunenässä saavuttivat 1990-luvun lopulla ja 2000-luvun alussa menestystä myös ulkomailla. Talouskriisistä toipuvassa yhteiskunnassa peliteollisuus alettiin nähdä uutena mahdollisuutena menestyä kansainvälisillä markkinoilla, ja valtio alkoi panostaa siihen enemmän. Vaikka Etelä-Korean hallitus oli tukenut teknologiateollisuutta ja tietoteknologista kehitystä jo 1990-luvun alusta alkaen, se on 2000-luvun taitteen jälkeen alkanut tukea myös peliteollisuutta vapauttamalla suoraan markkinoita, erottamalla ne uhkapelimarkkinoista ja tukemalla peliteollisuutta rahallisesti (Jin 2010, 50-54). Bora Nan mukaan hallitus vapautti myös peleihin liittyvää sääntelyä rankasti mahdollistaen entistä enemmän tuuriin ja uhkapelimäisiin rakenteisiin perustuvat ansaintamenetelmät, jotka puolestaan kasvattivat peliyhtiöiden tuottoja entisestään ( $\mathrm{Na} 2019$ ).

Vuonna 2006 niin peliteollisuus kuin hallituskin joutuivat uuden tilanteen eteen, kun moniin PC-bangeihin ja muihin pelihalleihin asennettujen Sea Story -peliauto- 
maattien huomattiin kiertävän rahapelaamisen kieltävää lainsäädäntöä. Vastaavia pelejä ja automaatteja oli monia muitakin, mutta Sea Story -pelistä tuli kriisin tunnetuin sen suosion takia. Alun perin kolikkopelimäiset automaatit sallittiin, kunhan ne eivät antaneet voittoina rahaa vaan erilaisia kulttuurilahjakortteja. Tarkoituksena oli tukea sekä korealaista peliteollisuutta että kulttuuriteollisuutta. Pelien ei pitänyt antaa suuria palkintoja kerralla, mutta koska niitä oli helppo muokata, ne usein antoivat jättipotteja. Kun kulttuurilahjakortit voitiin vaihtaa rahaan pientä komissiota vastaan, ne olivat käytännössä rahapelaamista, ja monet menettivätkin kaikki rahansa niiden parissa. Valtion herättyä tilanteeseen vuonna 2006 lakeja muutettiin ja Sea Story -pelin kaltaiset pelit kiellettiin. Tapaus kuitenkin jätti yleisön mielikuviin epäluuloja peliyrityksiä ja niiden ansaintamekanismeja kohtaan sekä epäuskon valtion kykyyn kontrolloida ja hallita peliteollisuutta. (Na 2019; Etnews 2012; Kim 2016; Chun \& Choi 2006.)

Bora Nan mukaan idea peleistä tavalla tai toisella vaarallisina tai haitallisina aktiviteetteina erityisesti lasten ja nuorten käytössä alkoi vuoden 2006 jälkeen saavuttamaan suosiota. Myös kirjallisuuskatsauksissa on huomattavissa selkeä kasvu haittoihin keskittyvässä tutkimuksessa vuoden 2006 jälkeen (Jeon 2010a; 2010b). Valtion rahoituslaitokset rahoittivat tutkimuksia aiheesta ja useampi niistä päätyi lopputulokseen, jonka mukaan pelit ovat addiktoivia ja niiden vaikutukset pelaajien aivoissa muistuttavat uhkapelaamista. Samaan aikaan peliteollisuus takoi edelleen loistavaa tulosta niin kotimaisilla kuin ulkomaisillakin markkinoilla, ja myös osa Korean hallituksesta koki peliteollisuuden tukemisen tarpeelliseksi pelaamisen mahdollisista haitoista huolimatta. Lopulta päädyttiin rajoittamaan lasten pelaamista mutta jättämään itse peliteollisuus suurimmaksi osaksi rauhaan. Nykyään online-pelien pelaaminen vaatii vahvaa tunnistautumista, jotta pelaajan ikä voidaan varmistaa.

Harvinaisempiin tutkimusteemoihin keskittyvän korealaisen pelitutkimuksen osalta nykytilanne on Bora Naan mukaan jokseenkin hankala. Valtion rahoituslaitokset tukevat edelleen varsin paljon haittoihin keskittyvää tutkimusta peliteollisuuden keskittyessä tukemaan tutkimusta, joka ajaa sen omia etuja ja voi johtaa korealaisten online-pelien entistä suurempaan menestykseen kansainvälisillä markkinoilla. Vaikka avoimia hakuja on alkanut ilmestyä aikaisempaa enemmän, ne ovat silti edelleen harvinaisia.

Tohtorikoulutettavien kohdalla tilanne on jopa muita haastavampi. Samanlaista järjestelmää kuin Suomessa, jossa yliopisto ja joukko muita rahoituslaitoksia tukevat väitöskirjatason tutkimusta varsin laajoilta näkökannoilta, ei oikeastaan ole. Jututtamieni tohtorikoulutettavien mukaan humanistiset ja sosiaalitieteiden väitöskirjat ovat yleensä enimmäkseen omarahoitteisia. Vanhempien tutkijoiden projekteissa työskentely on mahdollista, mutta tällöin akateemista vapautta oman tutkimuksen tekoon ei juurikaan ole. Vaikka nuori tutkija olisikin taloudellisessa tilanteessa, jossa hänellä on varaa rahoittaa tutkimuksensa itse, hänen on silti suostuteltava professori ohjaamaan tutkimusta, mikä voi pelitutkimuksen kaltaisessa korealaisittain epätyypillisen aihepiirin tutkimuksessa olla haastavaa. Varsinkaan jos tutkimusaihe ei istu vanhoihin tuttuihin näkökulmiin, nuoren tutkijan voi olla vaikea saada äänensä kuuluviin. Hierarkkisessa, autoritäärisessä ja maskuliinisessa yhteiskunnassa senioriteetti voi jyrätä uusien näkökulmien ja ideoiden yli.

\section{Toiveikas tulevaisuus}

Kuitenkin niin Bora Na kuin myös muut haastattelemani tutkijat ja tohtorikoulutettavat suhtautuvat tulevaisuuteen toiveikkaasti. Nuoriso pelaa paljon ja on kiinnostunut pelaamisesta monesta näkökulmasta. Vaikka pelitutkimukseen keskittyvät kurssit 
ovat edelleen harvinaisia, ne ovat yleensä täynnä aina kun niitä järjestetään. Monet vanhemmat tutkijat ovat entistä avomielisempiä uusia näkökulmia kohtaan, ja muuhun kuin teknologiaan ja haittoihin keskittyvän pelitutkimuksen suosio vaikuttaa olevan kasvussa. Myös peliteollisuus ja valtio näyttävät merkkejä positiivisemmasta suhtautumisesta ja voivat tulevaisuudessa nähdä pelikulttuurien tutkimuksen neutraalina vaihtoehtona aikaisemman voimakkaasti kahtia jakautuneen tutkimuskentän keskellä. Kun yhteiskunta alkaa nähdä peleissä itsessään arvoa sekä harrastuksena että tutkimuskohteena, on todennäköistä, että myös Koreasta alkaa ilmestyä enemmän meille tuttua pelitutkimusta. Haastateltavat olivat myös toiveikkaita uusien ideoiden ja nuorten tutkijoiden aseman parantumisen suhteen, sillä pelaamisen maineen parantuessa ja yhä useamman korealaisen professorin saadessa myös kansainvälistä kokemusta erityisesti amerikkalaisissa yliopistoissa, vanhat jäykähköt ajatukset ovat päässeet tuulettumaan. Kenties kymmenen vuoden kuluttua tullaan jokin pelitutkimuksen suurista akateemisista konferensseista järjestämään Koreassa, vaikkapa ensi kesänä Tampereella järjestettävä DiGRA.

\section{Lähteet}

Etnews, 17.9.2012, [100대 사건_074] 바다이야기 파문 <2006년 8월>, Etnews.com, Saatavilla: <http:// www.etnews.com/201209110606? $\mathrm{m}=1>$ (linkki tarkistettu 11.11.2019).

Jang, Ye-Beet (2013) 게임 내 스토리텔링 연구 메타분석: 게임·인문콘텐츠분야 학술지에 게재된 연구 논문을 중심으로 (Meta-Analysis on Game Storytelling Studies in Game and Content Research Fields). 영상문화, 21.

Jeon, Gyong-Ran (2010a) 한국 디지털게임 학술연구의 동향과 특징 (Analysis on the Trends and Characteristics of the Game Studies in Korea). 인문콘텐츠학회 (Korea Humanities Content Society), 18.

Jeon, Gyong-Ran (2010b) 인문 · 사회분야 학술지에 게재된 게임연구논문을 중심으로 (Meta-Analysis on Game Studies in the Field of Humanities and Social Science), 사이버 커뮤니케이션 학보 (Journal of Cybercommunication Academic Society), 23/3.

Jeong, E.J.; Ferguson, C.J. \& Lee, S. J. (2019) Pathological Gaming in Young Adolescents: A Longitudinal Study Focused on Academic Stress and Self-Control in South Korea, S.J. Journal of Youth Adolescence. Saatavilla: <https://doi.org/10.1007/s10964-019-01065-4> (linkki tarkistettu 11.11.2019).

Jin, Dal Yong (2010) Korea's Online Gaming Empire. Cambridge, Mass.: The MIT Press.

Kim, Tae-kyun (2016) <바다이야기 파문 10년> (1) '문어·고래' 쓰나미에 휩쓸린 한국, Yonhap News. Saatavilla: <https://www.yna.co.kr/view/AKR20160914053000017> (linkki tarkistettu 11.11.2019).

Kocca (2018) 2018 WHITE PAPER ON KOREAN GAMES SUMMARY, Korea creative Content Agency.

Kwak, H. H. (2019) 게임은 질병이다? "원인은 스트레스... 게임 금지해봤자 유튜브·SNS 중독될것", Hankook Ilbo. Saatavilla: <https://www.hankookilbo.com/News/Read/201905211178043629> (linkki tarkistettu 11.11.2019).

Na, Bora (2019) Henkilökohtainen haastattelu tekijän kanssa. Seoul, Etelä Korea.

South Korea Games Market 2018 (2018) Newzoo July 27 2018. Saatavilla: <https://newzoo.com/insights/ infographics/south-korea-games-market-2018/> (linkki tarkistettu 11.11.2019).

Taylor, T. L. (2012) Raising the Stakes: E-sports and the Professionalization of Computer Gaming. Cambridge, Mass.: The MIT Press. 